\title{
Assessment of mercury level in commonly consumed marine fishes in Malaysia
}

\begin{abstract}
Twelve species of common marine fish consumed by Malaysians were collected from local wholesale market in Malaysia; the mercury concentrations in muscle and liver samples were determined by cold vapour atomic absorption spectrophotometry. The mercury concentration in the samples, expressed in $\mu \mathrm{g} \mathrm{g}-1$ dry weight. It was 0.45 for short-bodied mackerel, 0.04 for scad, 0.04 for narrow-bodied Spanish mackerel, 0.13 for black pomfret, 0.50 for long tail tuna, 0.03 for greasy grouper, 0.09 for chacunda gizzard shad, 0.06 for yellow-banded scad, 0.05 for eastern little tuna, 0.09 for delagoa treadfish bream, 0.10 for giant perch and 0.00 for sardine's muscle tissue. Among the fishes analyzed, long tail tuna had the highest level followed by short-bodied mackerel. Significantly lower levels $(\mathrm{P}<0.05)$ of mercury were found in liver tissues. Total mercury concentration in liver tissues were as follow; 0.03 for short-bodied mackerel, 0.02 for scad, 0.05 for narrow-bodied Spanish mackerel, 0.10 for black pomfret, 0.49 for long tail tuna, 0.03 for greasy grouper, 0.03 for chacunda gizzard shad, 0.04 for yellow-banded scad, 0.02 for eastern little tuna, 0.09 for delagoa treadfish bream, 0.01 for giant perch and 0.01 for sardine. This study indicates that commonly consumed fish from Malaysia have concentrations of mercury below the permissible levels stated in the US FDA guidelines.
\end{abstract}

Keyword: Mercury; Marine fishes; Consumption; Malaysia 